\title{
Analisis Ekonomi terhadap Hukum Tindak Pidana Pencucian Uang
}

\author{
Ade Riyanda Prasetia Putra \\ Program Pascasarjana Fakultas HukumUniversitas Islam Indonesia \\ Jln. Cik Di Tiro No. 1, Yogyakarta, 55223 \\ adeyanda059@gmail.com
}

\begin{abstract}
Prevention and eradication of money laundering in Indonesia began on 17 April 2002 with the enactment of Law No. 15 of 2002 on Criminal Acts of Money Laundering. In fact, the stages of preventing money laundering were carried out before the law was enacted, but the scope was limited to banks. The purpose of this study is to analyze how is the law enforcement against economic violations in money laundering. The method used is the study of literature from libraries and the internet. The results of the study show that the enforcement of money laundering law or anti-money laundering regime is different from conventional criminal law enforcement. Disclosure of criminal acts and perpetrators of money laundering crimes is more referring to tracing the flow so it is not apparent that the funds originate from acts of illicit funds / money. At present, the eradication of money laundering in Indonesia is regulated in Law No. 8 of 2010 on Prevention and Eradication Criminal Acts of Money Laundering (Law 8/2010). Law No. 8 of 2010 replaces the previous law governing money laundering, namely Law No. 15 of 2002 as amended by Law No. 25 of 2003. Sanctions of money laundering in the form of imprisonment for a minimum of 5 years and a maximum of 15 years and a minimum fine of Rp. 5,000,000,000.00 and a maximum of Rp. 15,000,000,000.00.
\end{abstract}

Keywords: Criminal action; economy; money laundering

\begin{abstract}
Abstrak
Pencegahan dan pemberantasan pencucian uang di Indonesia dimulai sejak 17 April 2002 dengan berlakunya Undang-Undang No. 15 Tahun 2002 tentang Tindak Pidana Pencucian Uang. Sesungguhnya, tahapan pencegahan pencucian uang sudah dilakukan sebelum undang-undang tersebut lahir, namun lingkupnya hanya terbatas pada bank. Tujuan kajian ini adalah untuk menganalisa bagaimana penegakan hukum terhadap pelanggaran ekonomi dalam tindak pidana pencucian uang. Metode yang digunakan adalah studi literatur dari perpustakaan dan internet. Hasil kajian menyimpulkan bahwa penegakan hukum pencucian uang atau rezim anti-pencucian uang berbeda dengan penegakan hukum tindak pidana konvensional. Pengungkapan tindak pidana dan pelaku tindak pidana pencucian uang lebih merujuk pada penelusuran aliran sehingga tidak kelihatan sebenarnya dana tersebut semula berasal dari tindakan dana/uang haram. Saat ini, pemberantasan pencucian uang di Indonesia diatur dalam Undang-Undang Nomor 8 Tahun 2010 tentang Pencegahan dan Pemberantasan Tindak Pidana Pencucian Uang (UU 8/2010). UU 8/2010 tersebut menggantikan undang-undang sebelumnya yang mengatur tentang pencucian uang, yaitu UndangUndang Nomor 15 Tahun 2002 sebagaimana telah diubah dengan Undang- Undang Nomor 25 Tahun 2003. Sanksi tindak pidana pencucian uang berupa pidana penjara paling singkat 5 tahun dan paling lama 15 tahun dan denda paling sedikit Rp. 5.000.000.000,00 dan paling banyak Rp. $15.000 .000 .000,00$.
\end{abstract}

Kata-kata Kunci: Ekonomi; pencucian uang; tindak pidana 


\section{Pendahuluan}

Secara formal, upaya pencegahan dan pemberantasan pencucian uang di Indonesia telah dimulai sejak 17 April 2002 yaitu saat diberlakukannya UndangUndang Nomor 15 Tahun 2002 tentang Tindak Pidana Pencucian Uang. Sesungguhnya, tahapan pencegahan pencucian uang sudah dilakukan sebelum undang-undang tersebut lahir, namun lingkupnya hanya terbatas pada bank. Hal ini dapat ditunjukkan melalui seperangkat regulasi yang telah dikeluarkan oleh otoritas perbankan yang lebih dikenal dengan Peraturan Bank Indonesia tentang Prinsip Mengenal Nasabah. Urgensi pengaturan ini, tentu didasari oleh alasan yang kuat terutama mengenai dampak yang ditimbulkan oleh kegiatan pencucian uang dalam perekonomian dan untuk memenuhi prinsip-prinsip pengawasan bank secara efektif sesuai standar internasional.

Di bidang ekonomi, pencucian uang dapat merongrong sektor swasta yang sah karena biasanya pencucian uang tersebutdilakukan dengan menggunakan perusahaan-perusahaan (front companies) untuk mencampur uang haram dengan uang sah sehingga bisnis yang sah kalah bersaing dengan perusahaan-perusahaan tersebut; merongrong integritas pasar-pasar keuangan karena lembaga-lembaga keuangan (financialinstitutions) yang mengandalkan dana hasil kejahatan dapat menghadapi bahaya likuiditas; mengakibatkan hilangnya kendali pemerintah terhadap kebijakan ekonominya karena para pencuci uang menanamkan kembali dana-dananya bukan di negara-negara yang dapat memberikan ratesofreturn yang lebih tinggi tetapi diinvestasikan kembali di negara-negara dimana kegiatan mereka itu kecil kemungkinannya untuk dapat dideteksi; dan dapat menimbulkan distorsi dan ketidakstabilan ekonomi karena para pencuci uang tidak tertarik untuk memperoleh keuntungan dari investasi-investasi mereka tetapi mereka lebih tertarik untuk melindungi hasil kejahatan yang mereka lakukan dan dana yang mereka tempatkan secara ekonomis tidak harus bermanfaat bagi negara yang menerima penempatan. Bagi Pemerintah, dampak ikutan selanjutnya adalah meningkatnya kejahatan-kejahatan di bidang keuangan (financial crimes) dan menimbulkan biaya sosial yang tinggi (social cost) terutama untuk biaya dalam meningkatkan upaya penegakan hukumnya. 


\section{Rumusan Masalah}

Berdasarkan uraian tersebut di atas, rumusan permasalahan, yaitu: bagaimanakah cara menganalisis pelanggaran hukum terhadap ekonomi dalam tindak pidana pencucian uang?

\section{Tujuan Penelitian}

Berdasarkan dari rumuan permasalahan tunggal tersebt di atas, maka tujuan dari penelitian ini adalah untuk menganalisis pelanggaran hukum terhadap ekonomi dalam tindak pidana pencucian uang.

\section{Metode Penelitian}

Penelitian ini menggunakan metode penelitian normatif atau penelitian perpustakaan, ini merupakan penelitian yang mengkaji studi dokumen, yakni menggunakan berbagai data sekunder seperti peraturan perundang-undangan, keputusan pengadilan, teori hukum, dan dapat berupa pendapat para sarjana.

Penelitian jenis normatif ini menggunakan analisis kualitatif yakni dengan menjelaskan data-data yang ada dengan kata-kata atau pernyataan bukan dengan angka-angka. ${ }^{1}$

\section{Hasil Penelitian dan Pembahasan}

\section{Kaitan antara Hukum dan Ekonomi dalam Tindak Pidana Pencucian Uang}

Dalam Pasal 69 Undang-Undang Nomor 8 Tahun 2010 tentang Pencegahan dan Pemberantasan Tindak Pidana Pencucian Uang, yang formulasinya sebagai berikut:

“Untuk dapat dilakukan penyidikan, penuntutan, dan pemeriksaan di sidang pengadilan terhadap tindak pidana pencucian uang tidak wajib dibuktikan terlebih dahulu tindak pidana asalnya"

Tindak pidana asal adalah predicate offence, yaitu delik-delik yang menghasilkan criminal proceeds atau hasil kejahatan yang kemudian dicuci. Pasal 2 Undang-Undang Pencegahan dan Pemberantasan Tindak Pidana Pencucian Uang menyatakan bahwa:

1“PenelitianHukumNormatif”, https://idtesis.com,diaksestanggal 9 December 2019. 
(1)Hasil tindak pidana adalah Harta Kekayaan yang diperoleh dari tindak pidana:

a. korupsi;

b. penyuapan;

c. narkotika;

d. psikotropika;

e. penyelundupan tenaga kerja;

f. penyelundupan migran;

g. di bidang perbankan;

h. di bidang pasar modal;

i. di bidang perasuransian;

j. kepabeanan;

k. cukai;

1. perdagangan orang;

m.perdagangan senjata gelap;

n. terorisme;

o. penculikan;

p. pencurian;

q. penggelapan;

r. penipuan;

s. pemalsuan uang;

t. perjudian;

u. prostitusi;

v. di bidang perpajakan;

w. di bidang kehutanan;

x. di bidang lingkungan hidup;

y. di bidang kelautan dan perikanan; atau

z. tindak pidana lain yang diancam dengan pidana penjara 4 tahun atau lebih, yang dilakukan di wilayah Negara Kesatuan Republik Indonesia atau di luar wilayah Negara Kesatuan Republik Indonesia dan tindak pidana tersebut juga merupakan tindak pidana menurut hukum Indonesia.

(2)Harta Kekayaan yang diketahui atau patut diduga akan digunakan dan/atau digunakan secara langsung atau tidak langsung untuk kegiatan terorisme, organisasi teroris, atau teroris perseorangan disamakan sebagai hasil tindak pidana sebagaimana dimaksud pada ayat (1) huruf n.

Berdasarkan Pasal 2 ayat (1) tersebut, tindak pidana yang dimaksud dengan tindak pidana asal adalah pencucian hasil tindak pidana yang tindak pidananya tidak termasuk yang disebutkan dalam Pasal 2 ayat (1), bukan merupakan tindak pidana pencucian uang. ${ }^{2}$

${ }^{2}$ R. Wiyono, Pembahasan Undang-Undang Pencegaban dan Pemberantasan Tindak Pidana Pencucian Uang, cetakan ke-1, SinarGrafika, Jakarta Timur, 2014, hlm. 194. 
Dilihat dari Formulasi Pasal 69 UU PPTPPU, hal ini berarti bahwa tindak pidana pencucian uang adalah tindak pidana yang bisa disidik, dituntut dan dibawa ke pengadilan, tanpa harus membuktikan terlebih dahulu tindak pidana asalnya, misalnya atas tindak pidana pencucian uang yang tindak pidana asalnya berupa tindak pidana korupsi, maka untuk dilakukan penyidikan, penuntutan maupun persidangan atas perkara TPPU tidak harus menunggu dibuktikannya tindak pidana asalnya yang berupa korupsi. ${ }^{3}$ Dengan adanya ketentuan yang terdapat dalam Pasal 69 tersebut, hendak menunjukan bahwa tindak pidana pencucian uang sebagaimana dimaksud dalam Pasal 3, Pasal 4, dan Pasal 5 adalah ketentuan yang berdiri sendiri (independent crime).

\section{Peran Hukum Pidana terhadap Kejahatan Ekonomi dalam Tindak Pidana Pencucian Uang}

Peranan aturan hukum, merupakan salah satu bentuk sistem hukum yang paling utama dalam menanggulangi kejahatan pencucian uang sebagai salah satu bentuk kejahatan kontemporer dan canggih, Satjipto Rahardjo berpendapat, "Hukum bisa berfungsi untuk mengendalikan masyarakat dan bisa juga menjadi sarana untuk melakukan perubahan-perubahan dalam masyrakat."4 Perubahan tersebut harus ada peraturan perundang-undangan yang aktif dan efekti dalam mengatasi kejahatan pencucian uang. Saat ini menyangkut pemberantasan pencucian uang di Indonesia diatur dalam Undang-Undang Nomor 8 Tahun 2010 tentang Pencegahan dan Pemberantasan Tindak Pidana Pencucian Uang (disingkat dengan UU TPPU). UU TPPU tersebut menggantikan undang-undang sebelumnya yang mengatur pencucian uang yaitu, Undang-Undang Nomor 15 Tahun 2002 sebagaimana telah diubah dengan Undang- Undang Nomor 25 Tahun 2003.

Undang-undang yang lama, telah menunjukkan arah yang positif. Hal itu, tercermin dari meningkatnya kesadaran dari pelaksana undang-undang tentang tindak pidana pencucian uang, seperti penyedia jasa keuangan dalam

${ }^{3}$ Yudi Kristiana, Pemberantasan Tindak Pidana Pencucian Uang: Perspektif Hukum Progresif, Thafa Media, Yogyakarta, 2016, hlm. 157.

${ }^{4}$ Satjipto Rahardjo, Ilmu Hukum, cetakan ke-6, Citra Aditya Bakti, Bandung, 2006, hlm. 189. 
melaksanakan kewajiban pelaporan, Lembaga Pengawas dan Pengatur dalam pembuatan peraturan, Pusat Pelaporan dan Analisis Transaksi Keuangan (PPATK) dalam kegiatan analisis, dan penegak hukum dalam menindaklanjuti hasil analisis hingga penjatuhan sanksi pidana dan/atau sanksi administratif. ${ }^{5}$ Pusat Pelaporan dan Analisis Transaksi Keuangan yang selanjutnya disingkat PPATK adalah lembaga independen yang dibentuk dalam rangka mencegah dan memberantas tindak pidana Pencucian Uang. Dengan demikian PPATK merupakan struktur hukum (lembaga hukum) di Indonesia khususnya dibidang keuangan sebagai penegak hukum, tindak pidana pencuciann uang. ${ }^{6}$ Dalam melaksanakan tugas sebagaimana dimaksud tersebut PPATK menyelenggarakan fungsi sebagai berikut:

a. Pencegahan dan pemberantasan Tindak Pidana Pencucian Uang

b. Pengelolaan data dan informasi yang diperoleh PPATK

c. Pengawasan terhadap kepatuhan pihak pelapor

d. Analisis atau pemeriksaan laporan dan informasi transaksi keuangan yang berindikasi TPPU dan/atau tindak pidana lainnya. ${ }^{7}$

\section{Pengertian Kejahatan Ekonomi Dalam Tindak Pidana Pencucian Uang}

Mengacu pada UU TPPU, pencucian uang didefinisikan sebagai kegiatan: menempatkan, mentransfer, mengalihkan membelanjakan, membayarkan, menghibahkan, menitipkan, membawa ke luar negeri, mengubah bentuk, menukarkan dengan mata uang atau surat berharga atau perbuatan lain atas harta kekayaan yang diketahuinya atau patut diduganya merupakan hasil tindak pidana dengan tujuan menyembunyikan atau menyamarkan asal usul harta kekayaan (Pasal 3); menyembunyikan atau menyamarkan asal usul, sumber, lokasi, peruntukan, pengalihan hak-hak, atau kepemilikan yang sebenarnya atas harta kekayaan yang diketahuinya atau patut diduganya merupakan hasil tindak pidana (Pasal 4); dan menerima, menguasai penempatan, pentransferan, pembayaran, hibah, sumbangan, penitipan, penukaran, atau menggunakan harta

\footnotetext{
5Pusat Pelaporan Analisis dan Transaksi Keuangan (PPATK), Modul E-Learning 1 Pengenalan Anti Pencucian Uang Dan Pendanaan Terorisme, PPATK, Jakarta, hlm. 1.

${ }^{6}$ Pasal 1 ayat (2) Undang-Undang Nomor 8 Tahun 2010 tentang Pencegahan Dan Pemberantasan Tindak Pidana Pencucian Uang

${ }^{7}$ Muhammad Yusuf, Integritas Tanggung Jawab Profesionalisme Kerahasiaan, Laporan Akuntabilitas Kinerja Instansi Pemerintah Tahun 2011, PPATK, Jakarta, 2011, hlm. 2.
} 
kekayaan yang diketahuinya atau patut diduganya merupakan hasil tindak pidana (Pasal 5).

Dari definisi menurut UU TPPU di atas, Pusat Pelaporan dan Analisis Transaksi Keuangan (PPATK) dalam PPATKE-Learning (2014) mengelompokkan pelaku pencucian uang ke dalam 2 klasifikasi, yaitu pelaku pencucian uang aktif dan pelaku pencucian uang pasif. Pelaku pencucian uang aktif, yaitu pelaku yang memenuhi Pasal 3 dan Pasal 4 UU TPPU, dimana pelaku pencucian uang adalah sekaligus pelaku tindak pidana asal dan merupakan pihak yang mengetahui atau patut menduga bahwa harta kekayaan berasal dari hasil tindak pidana. Pelaku pencucian uang pasif, yaitu pelaku yang dikenakan Pasal 5 UU TPPU, dimana pelaku pencucian uang adalah pihak yang menikmati manfaat dari hasil kejahatan dan berpartisipasi menyembunyikan atau menyamarkan asal usul harta kekayaan.

\section{Motif Munculnya Kejahatan Ekonomi dan Urgensi Diaturnya Kejahatan Ekonomi dalam Hukum Pidana}

Motif munculnya kejahatan ekonomi pencucian uang adalah memberikan legitimasi pada dana yang diperoleh secara tidak sah. Walaupun dapat dikatakan tidak ada sistem pencucian uang yang sama, Pada dasarnya proses pencucian uang di lembaga keuangan atau perbankan dapat dikelompokkan ke dalam tiga tahap kegiatan, yaitu: placement, layering dan integration. ${ }^{8}$

\section{a. Placement}

Placement adalah upaya menempatkan dana yang dihasilkan dari suatu kegiatan tindak pidana ke dalam sistem keuangan. Bentuk kegiatan ini

1) Menempatkan dana pada bank. Kadang-kadang kegiatan ini diikuti dengan pengajuan kredit/pembiayaan.

2) Menyetorkan uang pada Penyedia Jasa Keuangan (PJK) sebagai pembayaran kredit untuk mengaburkan audit trail.

${ }^{8}$ Erman Rajagukguk, Rezim Anti Pencucian Uang Dan Undang-Undang Tindak Pidana Pencucian Uang, Makalah pada Lokakarya "Anti Money Laundering" Fakultas Hukum Universitas Sumatera Utara, Medan 15 September 2005, hlm. 2. 
3) Menyelundupkan uang tunai dari suatu negara ke negara lain. Membiayai suatu usaha yang seolah-olah sah atau terkait dengan usaha yang sah berupa kredit/pembiayaan, sehingga mengubah kas menjadi kredit/ pembiayaan.

4) Membeli barang-barang berharga yang bernilai tinggi untuk keperluan pribadi, membelikan hadiah yang nilainya mahal sebagai penghargaan/hadiah kepada pihak lain yang pembayarannya dilakukan melalui Penyedia JasaKeuangan (PJK).

\section{b. Layering}

Layering adalah memisahkan hasil tindak pidana dari sumbernya yaitu tindak pidananya melalui beberapa tahap transaksi keuangan untuk menyembunyikan atau menyamarkan asal-usul dana. Dalam kegiatan ini terdapat proses pemindahan dana dari beberapa rekening atau lokasi tertentu sebagai hasil placement ke tempat lain melalui serangkaian transaksi yang kompleks dan didesain untuk menyamarkan dan menghilangkan jejak sumber dana tersebut.

Bentuk kegiatan ini antara lain:

1) Transfer dana dari satu bank ke bank lain dan atau antar wilayah/negara.

2) Penggunaan simpanan tunai sebagai agunan untuk mendukung transaksi yang sah.

3) Memindahkan uang tunai lintas batas negara melalui jaringan kegiatan usaha yang sah maupun shell company

\section{c. Integration}

Integration adalah upaya menggunakan harta kekayaan yang telah tampak sah, baik untuk dinikmati langsung, diinvestasikan ke dalam berbagai bentuk kekayaan material maupun keuangan, dipergunakan untuk membiayai kegiatan bisnis yang sah, ataupun untuk membiayai kembali kegiatan tindak pidana. Dalam melakukan pencucian uang, pelaku tidak terlalu mempertimbangkan hasil yang akan diperoleh, dan besarnya biaya yang harus dikeluarkan, karena tujuan 
utamanya adalah untuk menyamarkan atau menghilangkan asal-usul uang sehingga hasil akhirnya dapat dinikmati atau digunakan secara aman. ${ }^{9}$

Integration dapat diartikan juga sebagai tahap dimana pelaku memasukkan kembali dana yang tidak tampak lagi asal usul aslinya kedalam transaksi yang sah, sehingga tidak kelihatan sebenarnya dana tersebut semula berasal dari tindakan ilegal. Integration, dilakukan dalam bentuk penjualan kembali saham, rumah, kapal atau perhiasan. ${ }^{10}$

Ketiga kegiatan tersebut di atas dapat terjadi secara terpisah atau simultan, namun umumnya dilakukan secara tumpang tindih.

\section{Perkembangan Kejahatan Ekonomi dalam Hukum Pidana di Indonesia}

Perkembangan kejahatan ekonomi saat ini banyak dilakukan dengan modus yang dibungkus dengan membentuk suatu badan hukum. Secara keperdataan badan hukum merupakan subjek hukum, karena dapat melakukan suatu perikatan/perjanjian/kerjasama dan dapat memperoleh keuntungan. Konsep pertanggungjawaban pidana oleh korporasi sebagai pribadi (corporate criminal liability) merupakan hal yang masih mengundang perdebatan. Banyak pihak yang tidak mendukung pandangan bahwa suatu korporsi yang wujudnya semu dapat melakukan suatu tindak kejahatan serta memiliki criminal intent yang melahirkan pertanggungjawaban pidana. Di samping itu, mustahil untuk dapat menghadirkan di korporasi dengan fisik yang sebenarnya dalam ruang pengadilan dan duduk di kursi terdakwa guna menjalani proses peradilan.

\section{Regulasi di Indonesia yang Berkaitan dengan Kejahatan Ekonomi}

Cakupan pengaturan sanksi pidana dalam Undang-Undang Nomor 8 Tahun 2010 tentang Pencegahan Dan Pemberantasan Tindak Pidana Pencucian Uang meliputi TPPU (tindak pidana pencucian uang) yang dilakukan oleh orang perseorangan, tindak pidana pencucian uang bagi korporasi, dan tindak pidana

${ }^{9}$ Pusat Pelaporan dan Analisis Transaksi Keuangan (PPATK), Pedoman Umum Pencegahan dan Pemberantasan Tindak Pidana Pencucian Uang bagi Penyedia Jasa Kenangan, PPATK, Jakarta, 2003, hlm. 4-5.

${ }^{10}$ Erman Rajagukguk, Op. Cit., hlm. 14. 
yang terkait dengan tindak pidana pencucian uang. TPPU dapat dikelompokkan dalam 2 klasifikasi, yaitu TPPU aktif dan TPPU pasif. ${ }^{11}$

Tindak pidana pencucian uang aktif sebagaimana dirumuskan dalam Pasal 3 dan 4 UU TPPU, lebih menekankan pada pengenaan sanksi pidana bagi:

a. Pelaku pencucian uang sekaligus pelaku tindak pidana asal dengan kegiatan menempatkan, mentransfer, mengalihkan, membelanjakan, membayarkan, menghibahkan, menitipkan, membawa ke luar negeri, mengubah bentuk, menukarkan dengan mata uang atau surat berharga atau perbuatan lainatas Harta Kekayaan yang diketahuinya atau patut diduganya merupakan hasil tindak pidana dipidana karena tindak pidana Pencucian Uang dengan pidana penjara paling lama 20 (dua puluh) tahun dan denda paling banyak Rp. 10,000,000,000.00 (sepuluh miliar rupiah).

b. Pelaku pencucian uang, yang mengetahui atau patut menduga bahwa harta kekayaan berasal dari hasil tindak pidana, seperti menyembunyikan atau menyamarkan asal usul, sumber, lokasi, peruntukan, pengalihan hak-hak, atau kepemilikan yang sebenarnya atas Harta Kekayaan yang diketahuinya atau patut diduganya merupakan hasil tindak pidana dengan. Adapun tindak pidananya berupa pidana penjara paling lama 20 (dua puluh) tahun dan denda paling banyak Rp. 5,000,000,000.00 (lima miliar rupiah).

Tindak pidana pencucian uang pasif sebagaimana dirumuskan dalam Pasal 5 UU TPPU lebih menekankan pada pengenaan sanksi pidana bagi pelaku yang menikmati manfaat dari hasil kejahatan, atau Pelaku yang berpartisipasi menyembunyikan atau menyamarkan asal usul harta kekayaan. Maksudnya setiap orang yang menerima atau menguasai penempatan, pentransferan, pembayaran, hibah, sumbangan, penitipan, penukaran, atau menggunakan Harta Kekayaan yang diketahuinya atau patut diduganya merupakan hasil tindak pidana. Di hukum dipidana dengan pidana penjara paling lama 5 tahun dan denda paling banyak Rp. 1,000,000,000.00.

Selain itu, setelah ada Undang Undang No. 8 Tahun 2010 tentang Pemberantasan Tindak Pidana Pencucian Uang, penyidik terhadap TPPU diperluas dari yang tadinya hanya oleh kepolisian saja menjadi wewenang oleh Komisi Pemberantasan Korupsi (KPK), Kejaksaan, Badan Nasional Narkotika (BNN), Bea Cukai dan Ditjen Pajak Kementerian Keuangan Republik Indonesia.

${ }^{11}$ Pusat Pelaporan Analisis dan Transaksi Keuangan (PPATK), Modul E-Learning... Loc. Cit. 
Dengan adanya perluasan kewenangan penyidik tersebut, Komisi Pemberantasan Korupsi (KPK) mulai berani menggunakan Undang-Undang Nomor 8 Tahun 2010 tentang Tindak Pidana Pencucian Uang untuk menjerat koruptor yang menyimpan dan uangnya di Perbankan.

\section{Permasalahan Pemberantasan Kejahatan Ekonomi di Indonesia}

Mardjono Reksodiputro menyatakan dalam bidang kriminologi juga banyak memberi perhatian pada masalah "white collar criminality", ini yaitu baik kejahatan di bidang ekonomi maupun kejahatan di bidang korupsi, karena keduanya sering berkaitan dan dilakukan oleh orang-orang yang yang terpandang di mata masyarakat serat dampak dari kejahatan ini sangat besar di bidang ekonomi suatu negara. ${ }^{12}$

Muladi, menyatakan fungsionalisasi hukum pidana dalam penanggulangan white collar crime bukanlah mudah, karena terdapat banyak kendala di Indonesia dalam praktik penanggulangan kejahatan tersebut, yaitu: ${ }^{13}$
a. Kejahatan sulit dilihat (low visibity);
b. Kejahatan sangat kompleks (complexity);
c. Penyebaran pertanggungjawaban (diffusion of responsibility);
d. Penyebaran korban yang luas (diffusion of victimization);
e. Kendala pedeteksian dan penuntutan (detection and prosecution);
f. Perauran yang tidak jelas (ambiguos laws);
g. Ambiguitas pelaku tindak pidana (ambiguous man of offenders).

Permasalahan akan segera muncul sehubungan dengan pertanggungjawaban pidana dari korporasi, karena asas utama dari pertanggungjawaban pidana adalah harus ada kesalahan (schuld) pada pelaku, sehingga bagaimanakah harus mengkonstruksikan kesalahan dari suatu korporasi, serta bagaimana pertanggungjawaban pidana dan unsur kesalahan pada korporasi, apakah tetap dapat dipertahankan seperti halnya pada manusia. Konsekuensi dari persoalan tersebut menjadikan peraturan perundang-undangan yang tidak spesifik merumuskan prinsip pertanggungjawaban pidana korporasi

\footnotetext{
${ }^{12}$ Hermansyah, Hukum Perbankan Nasional Indonesia, Prenada Media, Jakarta, 2005, hlm.136.

${ }^{13}$ Barda Nawawi Arief, Pembaharuan Hukum Pidana dalam Perspektif Kajian Perbandingan, Citra Aditya Bakti, Bandung, 2005, hlm.5.
} 
sulit untuk diaplikasikan sehingga memungkinkan timbulnya berbagai penafsiran.

\section{Penegakan Hukum terhadap Kejahatan Ekonomi di Indonesia}

Sistem dan mekanisme penegakan hukum pencucian uang atau rezim anti pencucian uang, berbeda dengan penegakan hukum tindak pidana konvensional. Pengungkapan tindak pidana dan pelaku tindak pidana pencucian uang lebih difokuskan pada penelusuran aliran sehingga tidak kelihatan sebenarnya dana tersebut semula berasal dari tindakan dana/uang haram (follow the money) atau transaksi keuangan. Dengan kata lain, penelusuran aliran dana melalui transaksi keuangan, merupakan cara yang paling mudah untuk menemukan jenis kejahatan, pelaku kejahatan dan tempat dimana hasil kejahatan disembunyikan atau disamarkan. ${ }^{14}$

Penelusuran Harta Kekayaan hasil tindak pidana pada umumnya dilakukan oleh lembaga keuangan melalui mekanisme yang diatur dalam peraturan perundang-undangan. ${ }^{15}$ Seperti penyedia jasa keuangan dalam melaksanakan kewajiban pelaporan, Lembaga Pengawas dan Pengatur dalam pembuatan peraturan, Pusat Pelaporan dan Analisis Transaksi Keuangan (PPATK) dalam kegiatan analisis, dan penegak hukum dalam menindaklanjuti hasil analisis hingga penjatuhan sanksi pidana dan/atau sanksi administratif. 19 Pusat Pelaporan dan Analisis Transaksi Keuangan yang selanjutnya disingkat PPATK adalah lembaga independen yang dibentuk dalam rangka mencegah dan memberantas tindak pidana Pencucian Uang. Dengan demikian, PPATK merupakan struktur hukum (lembaga hukum) di Idnonesia khususnya dibidang keuangan sebagai penegak hukum, tindak pidana pencucian uang. Dalam melaksanakan tugas sebagaimana dimaksud tersebut PPATK menyelenggarakan fungsi sebagai berikut:

a. Pencegahan dan pemberantasan Tindak Pidana Pencucian Uang

b. Pengelolaan data dan informasi yang diperoleh PPATK

c. Pengawasan terhadap kepatuhan pihak pelapor

d. Analisis atau pemeriksaan laporan dan informasi transaksi keuangan yang berindikasi TPPU dan/atau tindak pidana lainnya.

${ }^{14}$ Erman Rajagukguk, Op. Cit., hlm. 14.

${ }^{15}$ Lihat Penjelasan Undang-Undang Nomor 8 Tahun 2010 tentang Pencegahan dan Pemberantasan Tindak Pidana Pencucian Uang 
Peranan aturan hukum, merupakan salah satu bentuk sistem hukum yang paling utama dalam menanggulangi kejahatan pencucian uang sebagai salah satu bentuk kejahatan kontemporer dan canggih, Satjipto Rahardjo berpendapat "Hukum bisa berfungsi untuk mengendalikan masyarakat dan bisa juga menjadi sarana untuk melakukan perubahan-perubahan dalam masyrakat."16 Perubahan tersebut harus ada peraturan perundang-undangan yang aktif dan efekti dalam mengatasi kejahatan pencucian uang. Saat ini menyangkut pemberantasan pencucian uang di Indonesia diatur dalam Undang- Undang Nomor 8 Tahun 2010 tentang Pencegahan dan Pemberantasan Tindak Pidana Pencucian Uang (disingkat dengan UU TPPU). UU 8/2010 tersebut menggantikan undang-undang sebelumnya yang mengatur pencucian uang yaitu, Undang-Undang Nomor 15 Tahun 2002 sebagaimana telah diubah dengan Undang- Undang Nomor 25 Tahun2003.

\section{Penutup}

Setelah dikeluarkannya UU No. 25 Tahun 2003 tentang Pencucian Uang, berarti menganggap perbuatan pencucian uang sebagai tindak pidana (kejahatan) yang harus ditindak tegas oleh para penegak hukum yang berwenang. Dengan adanya perangkat hukum yang tegas hal ini bisa dijadikan sebagai perwujudan rasa keadilan. Sanksi tindak pidana pencucian uang berupa pidana penjara paling singkat 5 tahun dan paling lama 15 tahun dan denda paling sedikit Rp. 5,000,000,000.00 dan paling banyak Rp. 15,000,000,000.00.

Selain itu pihak yang terlibat seperti pelapor dan saksi memiliki perlindungan hukum dari kemungkinan ancaman yang membahayakan diri, jiwa, dan/atau hartanya termasuk keluarganya. Dalam kasus money laundering kepolisian dan penuntut umum juga memiliki kesulitan dalam membuktikan terjadinya tindak pidana pencucian uang karena modusnya yang bervariasi dan biasanya tidak ditemukan adanya cukup alat bukti.

${ }^{16}$ Satjipto Rahardjo, Op. Cit., hlm. 189. 


\section{Daftar Pustaka}

\section{Buku}

Arief, Barda Nawawi, Pembaharuan Hukum Pidana dalam Perspektif Kajian Perbandingan, Citra Aditya Bakti, Bandung, 2005.

Hermansyah, Hukum Perbankan Nasional Indonesia, Prenada Media, Jakarta, 2005.

Kristiana, Yudi, Pemberantasan Tindak Pidana Pencucian Uang: Perspektif Hukum Progresif, Thafa Media, Yogyakarta, 2016.

Pusat Pelaporan Analisis dan Transaksi Keuangan (PPATK), Modul E-Learning 1 Pengenalan Anti Pencucian Uang Dan Pendanaan Terorisme, PPATK, Jakarta.

Pusat Pelaporan dan Analisis Transaksi Keuangan (PPATK), Pedoman Umum Pencegahan dan Pemberantasan Tindak Pidana Pencucian Uang bagi Penyedia Jasa Keuangan, PPATK, Jakarta,2003.

Rahardjo, Satjipto, Ilmu Hukum, cetakan ke-6, Citra Aditya Bakti, Bandung, 2006.

Rajagukguk, Erman, Rezim Anti Pencucian Uang Dan Undang-Undang Tindak Pidana Pencucian Uang, Makalah pada Lokakarya "Anti Money Laundering" Fakultas Hukum Universitas Sumatera Utara, Medan 15 September 2005.

Wiyono, R., Pembahasan Undang-Undang Pencegahan dan Pemberantasan Tindak Pidana Pencucian Uang, cetakan ke-1, Sinar Grafika, Jakarta Timur, 2014.

Yusuf, Muhammad, Integritas Tanggung Jawab Profesionalisme Kerahasiaan, Laporan Akuntabilitas Kinerja Instansi Pemerintah Tahun 2011, PPATK, Jakarta, 2011.

\section{PeraturanPerundang-Undangan}

Undang-Undang Nomor 8 Tahun 2010 tentang Pencegahan Dan Pemberantasan Tindak Pidana Pencucian Uang

\section{Internet}

"Penelitian Hukum Normatif", https://idtesis.com,diaksestanggal 9 December 2019. 